\title{
Eksploitasi Tubuh Wanita dalam Iklan Dolce \& Gabbana
}

Tasya Nurian Afifah (Penulis Korespondensi)

Program Studi Ilmu Komunikasi, Universitas Muhammadiyah Yogyakarta, Indonesia taszyaakk@gmai.com

Azizah Wiladatur Rahma

Program Studi Ilmu Komunikasi, Universitas Muhammadiyah Yogyakarta, Indonesia azizahwrahmaa@gmail.com

Yusack Tri Nur Cholis

Program Studi Ilmu Komunikasi, Universitas Muhammadiyah Yogyakarta, Indonesia yusacknurcholis10@gmail.com

Diserahkan: 30 April 2020; Direvisi: 09 Oktober 2020; Diterima: 10 Oktober 2020

\begin{abstract}
Advertising is a medium for promoting a product or brand. Many advertisers compete in search of ways to appeal to customers to buy goods from the public. One way to achieve this, is by displaying a female sensuality side. The female sensuality has been an added spice to an advert, for women have always been attractive to an object of advertisers and made a mere profit. The study was designed to analyze the 2007 dolce $\mathcal{E}$ gabbana AD that exploited the body of women. The research method used was a descriptive and semiotical analysis of Roland barthes that developed the thinking of Ferdinand DE saussure. An analysis of the AD signs in the 2007 dolce $\mathcal{E}$ gabbana press from the facial expressions, body poses, the clothes used, number of man in the picture to the ads' drawing techniques.

Keyword: Dolce $\mathcal{E}$ gabbana, Exploitation, Sensuality, Women
\end{abstract}

\begin{abstract}
Abstrak
Iklan merupakan suatu media untuk mempromosikan sebuah produk atau brand. Banyak pengiklan berlomba-lomba mencari cara untuk menarik minat pembeli agar barangnya dibeli oleh masyarakat. Salah satu cara untuk mencapai hal tersebut, adalah dengan menampilkan sisi sensualitas dari perempuan. Sisi sensualitas dari perempuan menjadi bumbu tambahan dalam sebuah iklan, perempuan selalu menarik untuk dijadikan objek bagi para pengiklan dan hanya dijadikan sebagai penambah keuntungan semata. Penelitian ini dirancang untuk menganalisis iklan Dolce \& Gabbana pada tahun 2007 yang mengeksploitasi tubuh dari perempuan. Metode penelitian yang digunakan adalah dengan metode deskriptif dan analisis semiotika Roland Barthes yang mengembangkan pemikiran dari Ferdinand De Saussure. Analisis yang dilakukan yaitu dengan melihat tanda-tanda yang muncul dalam gambar iklan di media cetak Dolce \& Gabbana tahun 2007, mulai dari ekspresi wajah, pose tubuh, busana yang digunakan, jumlah pria dalam gambar, hingga teknik pengambilan gambar dalam iklan tersebut.
\end{abstract}

Kata Kunci: Dolce \& Gabbana, Eksploitasi, Perempuan, Sensualitas

\section{PENDAHULUAN}

Iklan diartikan sebagai sebuah bentuk kegiatan mengkomunikasikan, menarik perhatian, dan membujuk sebagian atau seluruh lapisan masyarakat untuk mengambil tindakan dalam merespon ide barang atau jasa yang dikomunikasikan. Berdasarkan dari hal tersebut banyak produk yang bersaing untuk bisa mendapat perhatian dari masyarakat, salah satunya adalah dengan menampilkan model wanita yang menampilkan sisi sensualitas untuk mendapat perhatian dari masyarakat dan bisa bersaing dengan produk lainnya.

Media massa dan perempuan adalah dua hal yang hampir selalu berkaitan. Ini sangat terasa ketika kita bicara mengenai representasi perempuan dalam media massa yang diwarnai dengan "eksploitasi" perempuan dalam bentuk stereotipe dan komoditas alias pelaris produk. Fenomena pengeksploitasian 
tubuh perempuan sudah terjadi sejak lama, dari hal kecil misalnya penggunaan model perempuan terutama yang difokuskan pada bagian tubuh perempuan, yang banyak mengumbar sosok perempuan hanya dari aspek kecantikan, kemolekan, dan keindahan tubuh.

Salah satu contohnya adalah iklan Dolce \& Gabbana, salah satu brand fashion yang berasal dari Italia. Pada tahun 2007, Dolce \& Gabbana membuat iklan busana yang menampilkan sisi sensualitas dari seorang wanita. Dalam iklan tersebut menampilkan ekspresi wajah model wanita yang menggoda, ia berbaring menghadap ke atas dan di atas wanita tersebut ada seorang pria yang ingin menciumnya. Di sekitar wanita tersebut juga ada tiga pria lain yang memandangi tubuh wanita itu dengan wajah ingin bercumbu, wanita tersebut memakai pakaian minim berwarna hitam dengan buah dada yang terlihat sedikit dan paha yang terlihat tanpa sehelai kain pun. Dalam iklan tersebut model wanita juga terlihat pasrah jika para lelaki itu ingin mencumbu dirinya. Hal ini menunjukkan bahwa wanita selalu menjadi objek untuk dieksploitasi.

\section{KAJIAN PUSTAKA}

Penelitian terdahulu yang dilakukan oleh Dewi Novita Sari (2010) menemukan bahwa iklan lipstick Dolce \& Gabbana dalam majalah Harper's Bazaar edisi Agustus 2009 menampilkan sisi sensualitas dari seorang wanita. Hal ini terbukti dengan melakukan pendekatan semiotik pada iklan lipstick Dolce \& Gabbana, melalui pendekatan tersebut Dewi Novita Sari menemukan bahwa konsep sensualitas pada perempuan sebagai makhluk yang digunakan untuk menarik perhatian karena memiliki daya tarik fisik dan sebagai objek seks sesuai setereotipe media yaitu tubuh seksi. Dalam iklan tersebut juga terdapat pemaknaan tanda yang berupa kata-kata, gambar, dan warna yang digunakan untuk menarik perhatian, ini menunjukkan bahwa sejak dahulu wanita selalu menjadi objek untuk di eksploitasi dalam media apapun.

Berbeda dengan penelitian dari Dewi Novita Sari di atas, penelitian ini menggunakan objek iklan yang berbeda versi. Jika Dewi Novita Sari meneliti tentang iklan Dolce \& Gabbana versi lipstick, maka penelitian ini akan membahas tentang eksploitasi wanita dalam iklan Dolce \& Gabbana versi iklan busana pada tahun 2007. Dengan demikian, penelitian ini bertujuan untuk mengetahui eksploitasi wanita dalam iklan busana yang dilakukan oleh brand fashion Dolce \& Gabbana pada tahun 2007.

\section{KERANGKA TEORI}

\section{EKSPLOITASI PEREMPUAN}

Perempuan bukanlah sebuah fakta yang stabil, melainkan lebih merupakan keadaan yang selalu berada dalam proses menjadi sesuatu. Itu berarti segala kemungkinan yang dimiliki perempuan harus terdefinisi, tubuh merupakan situasi dan tubuh merupakan sketsa rencana hidup kita. Meski tubuh tidak bisa mendefinisikan secara sendiri tetapi tubuh menjadi satu elemen penting untuk menjadi seorang individu tertentu. Tubuh adalah situasi yang berbeda tanpa kehilangan kesempatan untuk menikmatinya atau mengatasinya jika situasi itu dianggap bermasalah (Priyatna, 2014:112). Berdasarkan teori di atas maka bisa diasumsikan bahwa tubuh perempuan adalah bentuk definisi dari berbagai kepentingan, contohnya model iklan perempuan dalam iklan.

Pada dasarnya model tersebut tidak mendefinisikan dirinya sendiri, melainkan mendefinisikan kepentingan pengiklan, mendefinisikan situasi serta pihak lain yang ikut serta di balik layar terbentuknya sebuah iklan.Iklan merupakan sarana untuk mempromosikan suatu produk yang ditujukan kepada calon konsumen atau masyarakat. Iklan yang baik adalah iklan yang mampu mendorong konsumennya untuk membeli produk yang dipromosikan dan sekaligus berhasil membentuk persepsi merek yang kuat dalam bemak target konsumen (Agung, 2003:152). Sebuah iklan 
yang dipasang pasti memiliki tujuan dan mengharapkan umpan balik dari masyarakat, serta iklan yang efektif adalah iklan yang mampu membangun persepsi masyarakat yang baik terhadap iklan.

Eksploitasi perempuan tersebut meletakkan perempuan sebagai kaum yang disubordinasikan. Perempuan bukan hanya dimanfaatkan citra dan tandanya sebagai daya tarik, tetapi juga dikomoditikan dan dilektakkan sebagai objek pemuas kebutuhan seks kaum laki-laki demi mendapatkan keuntungan (Prasetyo et al.,2012).

Pengambilan gambar pada saat peliputan masih menempatkan perempuan sebagai objek pandangan (male gaze) bagi camera person. Teknik sinematik yang digunakan adalah close up dan medium shot untuk melihat wajah perempuan., dan tilt up dan zoom in untuk melihat bagian tubuh perempuan. Begitu pula pada tahap editing visual berita gambar perempuan semacam ini dengan mudah lolos dan dipakai sebagai visual berita. Hal ini sering terjadi karena persepsi (mindset) camera person dan editor visual masih menempatkan bahwa gambar wajah perempuan dianggap lebih indah, menarik, dan eye catching sehingga dapat menjadi bumbu dalam visual berita.

Tubuh perempuan berpotensi untuk dieksploitasi karena tubuh perempuan memiliki nilai ekonomis yang tinggi dalam industri media. Sebagian besar iklan menggunakan tubuh perempuan untuk menarik minat dari konsumen. Tampilan tubuh perempuan dalam dunia iklan ditujukan untuk kepentingan laki-laki, sehingga gambaran dari perempuan dibentuk dari sudut pandang laki-laki. Media selalu mencari sesuatu untuk mempertahankan dominasi, entah dalam hal ekonomi, kekuasaan, maupun politis. Salah satu hal yang sangat disukai oleh pasar adalah menonjolkan seksualitas dari perempuan, karena seksualitas dari perempuan selalu menarik untuk dijadikan objek.

\section{IKLAN}

Iklan seharusnya menjadi sarana yang baik untuk menyampaikan informasi sebuah produk kepada masyarakat, bukan untuk ajang bersaing dengan kompetitor. Banyak iklan saat ini yang memunculkan foto atau gambar yang bersifat negatif, seperti iklan Dolce \& Gabbana yang memunculkan sisi sensualitas dari wanita. Iklan Dolce \& Gabbana sendiri mengiklankan produknya melalui media cetak. Media cetak adalah suatu media yang statis dan mengutamakan pesan-pesan visual. Media ini terdiri dari lembaran dengan sejumlah kata, gambar, atau foto, dalam tata warna dan halaman putih, memiliki fungsi utama memberi informasi dan menghibur. Iklan cetak merupakan teks yang kompleks dimana dalam mengkonstruksikan pesan menggunakan bahasa visual. Media cetak sendiri lebih menspesialkan produknya untuk menjangkau konsumen tertentu. Penampilan perempuan memiliki daya tarik yang tinggi, karena itulah dari segi bisnis memiliki harga jual yang tinggi juga. Perempuan tidak lagi dinilai dari segi kapasitas intelektual atau kualitas spiritualnya, tetapi lebih kepada materi atau penampilan luarnya. Perempuan selalu memeriahkan jagat periklanan baik melalui media cetak maupun media elektronik.

Kehadiran sosok perempuan menjadi bumbu penyedap dalam media massa. Saat ini, ketika karyakarya seni kreatif seperti iklan menjadi konsumsi masyarakat dalam berbagai media massa, posisi perempuan ini menjadi sangat potensial untuk dikomersialkan dan dieksploitasi, karena posisi perempuan menjadi sumber inspirasi dan juga tambang uang yang tak habis-habis (Burhan Bungin, 2003).

\section{METODE PENELITIAN}

Jenis penelitian yang digunakan dalam penelitian ini adalah deskriptif kualitatif dengan paradigma kritis. Secara lebih operasional, penelitian ini menggunakan metode semiotika untuk menganalisis obyek penelitian. Obyek penelitian dalam penelitian ini adalah iklan Dolce \& Gabbana tahun 2007, yang mengeksploitasi sisi sensualitas tubuh wanita. Obyek penelitian ini dianalisis dengan 
menggunakan analisis semiotika Roland Barthes yang mengembangkan pemikiran dari Ferdinand De Saussure.

Roland Barthes melanjutkan pemikiran Saussure dengan memberi telaah pada interaksi antara teks dengan pengalaman personal dan kultural penggunanya. Interaksi antara konvensi dalam teks dengan konvensi yang dialami dan diharapkan oleh penggunanya. Gagasan Barthes ini dikenal dengan tatanan penandaan (order of signification), yang meliputi primary signification atau denotasi (makna sebenarnya sesuai kamus) dan secondary signification atau konotasi (makna ganda yang timbul dari pengalaman kultural dan personal). Makna konotasi inilah yang kemudian berkembang dan menjadi mitos. Dalam penelitian ini, penulis berusaha melakukan analisis semiotika, mulai dari primary signification hingga secondary signification pada iklan Dolce \& Gabbana 2007.

\section{HASIL DAN PEMBAHASAN}

\section{TUBUH PEREMPUAN SEBAGAI OBYEK TATAPAN SEKSUAL}

Penggunaan perempuan dalam iklan bisa menambah daya tarik khalayak untuk menikmati pesan iklan. Perempuan adalah bumbu dari sebuah iklan. Iklan dipercaya akan mampu mendapatkan pengaruh besar jika menggunakan perempuan sebagai salah satu ilustrasi atau modelnya, bahkan sekalipun produk yang ditawarkan tersebut bukan dimaksudkan untuk digunakan oleh perempuan (Widyatama, 2007). Selain itu, jika kita mencoba mengambil surat kabar secara acak maka kita akan sering menemukan gambar visual beserta ulasan-ulasan yang secara terang-terangan menyampaikan pesan-pesan seksual (Juditha, 2015).

Dalam iklan banyak memuat makna eksploitasi organ tubuh dan daya tarik sensualitas perempuan. Terbukti dimana ketika perempuan distereotipkan secara sosial, nilai lebihnya itu hanya terdapat pada daya tarik seksualnya, yang terletak pada kecantikan, kemulusan, kesegaran, serta kemontokan tubuh modelnya (Kasiyan, 2008). Saat ini tubuh perempuan telah dikonstruksi bukan menjadi milik perempuan itu sendiri. Pada setiap detail-detail bagian tubuh perempuan menjadi kepentingan dari yang lain, perempuan dihargai sekaligus dijatuhkan karena tubuhnya. Pada sisi yang lain, perempuan dilihat karena fungsi reproduksinya. Fungsi biologis ini juga menjadikan perempuan dalam peran-peran pengasuhan, perawatan, tuntutan sikap kasih sayang dan kelembutan. Disisi yang lain lagi tubuh perempuan juga didefinisikan sebagai tubuh yang memiliki sensualitas serta dapat menimbulkan hasrat seksual dari laki-laki.

Perempuan merupakan salah satu bagian terpenting dalam pembuatan iklan Dolce \& Gabbana. Pesona perempuan dalam iklan Dolce \& Gabbana ini dipergunakan agar iklan lebih menarik dan mudah di ingat oleh siapapun yang melihatnya. Iklan-iklan yang membuat standar tubuh perempuan ideal membuktikan bagaimana laki-laki menciptakan perempuan untuk sesuai dengan fantasi mereka tentang "perempuan sexy atau cantik". Model-model perempuan adalah obyek yang dikreasi untuk mencapai fantasi tersebut, sedangkan laki-laki adalah penciptanya. Hal ini membuat perempuan berada pada posisi yang dirugikan (Astuti, 2016). Iklan Dolce \& Gabbana menggunakan model perempuan karena dianggap sebagai bentuk keindahan dan memiliki daya tarik tersendiri. 


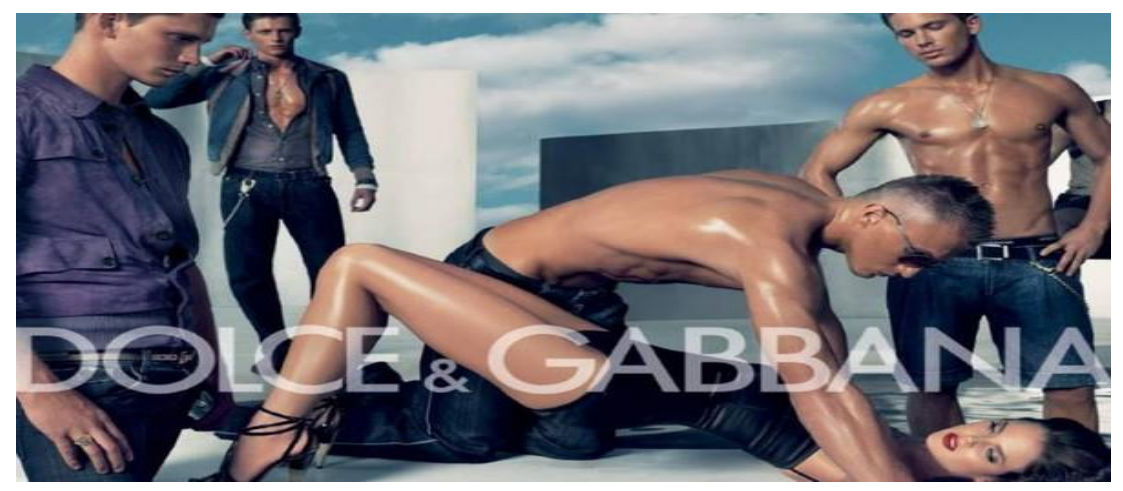

Gambar 1. Iklan fashion Dolce \& Gabbana (Fashionmagazine.com, 2018)

Gambar model pada iklan Dolce \& Gabbana tersebut bisa dikatakan tergolong ke dalam gambar pornografi. Dalam sudut pandang feminis, pornografi diartikan sebagai penggunaan representasi perempuan (tulisan, gambar, foto, video, film) dalam rangka manipulasi hasrat (desire) orang yang melihat, yang di dalamnya berlangsung proses degradasi perempuan dalam statusnya sebagai obyek seksual laki-laki (Piliang, 2010). Dalam iklan tersebut sangat terlihat bahwa sensualitas perempuan sangat ditonjolkan dan dikuatkan, pakaian dari wanita tersebut sangat minim dan menunjukkan wajah pasrah ketika ingin dicumbu oleh para lelaki di sekelilingnya.

Hal ini selaras dengan teori male gaze camera. Teori male gaze berasal dari dua teori yakni psikoanalisis teori dan feminist teori. Psikoanalistik teori menyatakan bahwa setiap manusia berpikir dan aksi tersebut didorong oleh faktor emosional dan psikologi dari dalam sering berada di luar kesadaran seseorang (Baran dan Dabis 2012). Teori yang kedua, berasal dari teori fenimis. Teori feminis merupakan perpanjangan dari aliran feminism dalam diskursus filosofis dan teoritis. Hal tersebut bertujuan untuk memahami sifat dasar ketidakadilan gender (Brabeck dan Brown, 1997).

\section{EKSPLOITASI WANITA DALAM DOLCE \& GABBANA}

Eksploitasi fisik dalam iklan Dolce \& Gabbana ini terlihat pada gambar yang menunjukkan bagianbagian tubuh tertentu seperti rambut, alis, mata, bibir, pundak, dada (payudara), serta disertai bahasa tubuh dan mimik wajah yang menunjang terbentuknya image seksi pada iklan ini. Dalam iklan tersebut ingin menunjukkan makna denotasi yaitu wanita yang dikelilingi oleh beberapa lelaki, serta wanita tersebut terlihat pasrah dan tidak berdaya dihadapan para lelaki tersebut. Iklan Dolce \& Gabbana ini ingin menunjukkan konotasi bahwa perempuan selalu menjadi objek untuk di eksploitasi dan dijadikan tontonan atau fantasi bagi para laki-laki. Iklan tersebut seperti menampilkan aktivitas gang bang, gang bang adalah perilaku seksual yang melibatkan lebih dari dua orang dan tak sedikit orang mengidentikkan gang bang sebagai perilaku pemerkosaan.

Dari makna konotasi di atas, dapat diketahui bahwa unsur sensualitas dan seksualitas perempuan ditampilkan melalui ekspresi wajah model, pose model, dan pakaian model. Dolce \& Gabbana menampilkan eksploitasi perempuan dari sisi sensualitas dan seksualitasnya dalam rangka membentuk dan mempertahankan citra dari brand serta untuk menarik perhatian konsumennya. Tubuh perempuan dalam iklan seringkali ditampilkan sebagai simbol kenikmatan, keindahan, dan keanggunan dari sebuah produk.

Kenikmatan visual biasanya dipahami sebagai sesuatu kenikmatan erotis yang diperoleh pada saat melihat orang lain atau memandang pada foto/gambar tubuh orang lain. Foto ini seakan mengakomodasi fantasi laki-laki yang selalu ingin mendapatkan kepuasan seksual lewat perempuan. Wajah, ekspresi, dan sikap tubuh model sangat mendukung hal itu (Handayani, 2017). Teknik foto 
yang digunakan dalam iklan tersebut adalah medium shoot, yaitu salah satu teknik foto dengan cara memotret objek dengan jarak yang tidak terlalu dekat tetapi juga tidak terlalu jauh dengan objek. Teknik seperti ini dilakukan untuk menggambarkan objek utamanya yaitu perempuan, tetapi juga memperlihatkan suasana disekitarnya.

Eksploitasi perempuan dalam pencitraan iklan tidak saja karena kerelaan perempuan, namun juga karena kebutuhan kelas sosial itu sendiri. Sehingga mau ataupun tidak kehadiran perempuan dalam kelas sosial itu, masih menjadi bagian dari refleksi realitas sosial masyarakatnya. Konsep mengenai perempuan, sering kali dikaitkan dengan keindahan tubuh serta kecantikan. Terlebih yang terdapat pada media, banyak iklan di media baik media cetak maupun elektronik yang menggunakan model perempuan sebagai objek untuk mempromosikan produk. Tentunya ada faktor-faktor tertentu yang berusaha dibuat oleh sebuah agensi iklan, agar pesan yang ingin disampaikan oleh sebuah produk dapat tersampaikan dengan baik kepada para calon konsumen.

Bagi Gilman (dalam Sue Thornham, 2000), laki-laki adalah pasar dan perempuan adalah pasokannya. Oleh karena itulah perempuan selalu menjadi objek dalam media, karena perempuan akan disesuaikan dengan apa yang diinginkan oleh para kaum laki-laki. Inilah mengapa seksualitas sangat menarik dalam media, karena seksualitas yang ditonjolkan atau ditampilkan itulah yang membuat media menjadi laku serta para kaum lelaki menemukan apa yang diinginkannya dalam media tersebut.

\section{STEREOTIPE MEDIA TERHADAP PEREMPUAN}

Media mempunyai peran yang besar dalam pembentukan stereotipe atas kecantikan baik wajah maupun tubuh dari perempuan. Kecantikan menurut media selalu dicirikan dengan tampilan fisik yang sangat menarik, hal itu diwujudkan dalam bentuk keindahan perempuan. Jika seorang perempuan cantik dan memiliki bentuk tubuh yang langsing serta seksi maka para lelaki akan memperebutkannya. Hal ini tercermin pada gambar yang ada di dalam iklan Dolce \& Gabbana, dimana seorang perempuan berparas cantik dan bertubuh seksi dikelilingi empat orang lelaki yang seperti ingin memperebutkannya.

Efek media juga akan semakin lebih kuat karena sosok perempuan yang ditampilkannya adalah salah satu cara untuk memperkokoh stereotipe yang sudah terbangun di tengah masyarakat. Oleh karena itu mengapa media ikut serta memperkokoh, melestarikan, bahkan memperburuk ketidakadilan terhadap perempuan di tengah masyarakat. Ketika sebuah media massa menyajikan sebuah fakta tentang perempuan secara konsisten, masyarakat akan menyangka bahwa tindakan paling tepat atau logis adalah mempercayai apa yang dikatakan oleh media.

Dalam media, perempuan yang cantik selalu diidentikkan dengan kulit putih, berambut lurus dan panjang, bertubuh langsing dan seksi, menggunakan busana mini atau busana yang mengikuti lekukan tubuh karena hal tersebut dianggap pilihan paling ideal dalam kehidupan bermasyarakat. Media secara perlahan akan menguatkan stereotipe tersebut saat perempuan secara terus-menerus ditampilkan sebagai objek seks dalam media, maka kaum lelaki akan menerima pembenaran dalam memandang perempuan sebagai objek yang fungsinya adalah sebagai pemuas nafsu seksual dari laki-laki. Hal ini mengakibatkan timbulnya anggapan bahwa kekuatan utama dari seorang perempuan adalah tubuhnya, bukan faktor yang lain seperti keunggulan intelektual, kecakapan bekerja, keluasan wawasan, dan yang lainnya.

Penggambaran dari media yang sampai ke masyarakat selalu memposisikan tubuh wanita sebagai salah satu hal yang dijadikan sebagai objek. Terlihat perbedaan dalam menampilkan citra laki-laki dan perempuan oleh media. Laki-laki sebagai subjek yang memiliki kendali serta hasrat kepada perempuan, sedangkan perempuan sebagai objeknya. Terlebih, objek fantasi bagi laki-laki yang mempertontonkan bagian tubuhnya sebagai suatu bentuk kepuasan. Dalam realitas sehari-hari, perempuan sudah dikonstruksikan sebagai objek yang akan dilihat dan laki-laki berperan sebagai pemilik tatapan. 
Perempuan menginternalisasikan pandangan laki-laki sebagai pengawasnya (Wells, 2015). Tubuh perempuan dijadikan seolah-olah sebagai alat tukar dengan keuntungan pelaku industri. Tubuh perempuan yang diekspos oleh media menjadikan perempuan sebagai objek yang diperjualbelikan dengan timbal balik rating, laba industri, dan lain sebagainya. Pada akhirnya, perempuan tidak bisa memiliki tubuhnya sendiri.

\section{KESIMPULAN}

Iklan digunakan sebagai media untuk mengkomunikasikan dan menarik perhatian sebagian atau seluruh lapisan masyarakat untuk merespon suatu barang atau jasa yang dikomunikasikan. Untuk itu, tak jarang beberapa iklan memang berlomba-lomba menggunakan ide se menarik mungkin untuk konsumen nya. Salah satu cara yang digunakan adalah dengan menggunakan model wanita yang menunjukkan sisi sensualitas sebagai objek agar mendapat nilai lebih di masyarakat. Hal ini dikarenakan ketika distereotipkan secara sosial, nilai lebihnya terdapat pada daya tarik seksualnya, yang terletak pada kecantikan, kemulusan, kesegaran, serta kemontokan tubuh modelny. Salah satu iklan yang menerapkan hal tersebut adalah Iklan busana milik Dolce \& Gabbana. Iklan tersebut banyak menuai kontroversi karena dianggap terlalu mengeksploitasi tubuh wanita yang menjadi modelnya. Iklan Dolce \& Gabbana ini ingin menunjukkan konotasi bahwa perempuan selalu menjadi objek untuk di eksploitasi dan dijadikan tontonan atau fantasi bagi para laki-laki. Iklan tersebut seperti menampilkan aktivitas gang bang, gang bang adalah perilaku seksual yang melibatkan lebih dari dua orang dan tak sedikit orang mengidentikkan gang bang sebagai perilaku pemerkosaan. Dalam iklan ini juga merepresentasikan seolah-olah wanita hanya sekedar pemuas nafsu dan menjadi golongan yang lemah. Iklan ini banyak menuai kontroversi karena dianggap melanggar aturan yang berlaku dan juga dianggap merendahkan martabat wanita.

\section{PERSANTUNAN}

Terima kasih kepada Dr. Fajar Junaedi yang telah membimbing proses riset dalam mata kuliah Kajian Kritis Iklan di Program Studi Ilmu Komunikasi UMY, selama satu semester genap tahun akademik 2019/2020 yang menghasilkan luaran berupa artikel ini.

\section{REFERENSI}

Agung, Y. (2003). 101 Konsultasi Praktis Pemasaran 1. Jakarta: Elex Media Komputindo.

Astuti, Y. D. (2016). Media dan Gender (Studi Deskriptif Representasi Stereotipe Perempuan dalam Iklan di Televisi Swasta). Profetik Jurnal Komunikasi, 9(2), 27-28.

Bungin, B. (2003). Analisis Data Penelitian Kualitatif: Pemahaman Filosifis dan Metodologis ke Arah Penguasaan Model Aplikasi. Jakarta: Raja Grafindo Persada.

Handayani, R. (2017). Male Gaze dalam Fotografi Model: Objektifikasi dan Komersialisasi Tubuh Perempuan. Jurnal Jurnalisa: Jurnal Jurusan Jurnalistik, 3(1).

Haryanto, T., \& Wahyudi, D. (2017). Eksploitasi Perempuan dalam Media Massa dan Tinjauan Islam. Martabat: Jurnal Perempuan dan Anak, 1(2), 279-300.

Juditha, C. (2015). Gender dan Seksualitas dalam Konstruksi Media Massa. Jurnal simbolika, 1(1), 6-14. Kasiyan. (2008). Manipulasi dan Dehumanisasi Perempuan dalam Iklan. Yogyakarta: Ombak.

Piliang, Y. A. (2010). Kode, Gaya, dan Matinya Makna: Semiotika dan Hipersemiotika. Bandung: Matahari Priyatna, A. (2014). Perempuan Dalam Tiga Novel Karya NH. Dini. Bandung: Matahari.

Thornham, S. (2000). Teori Feminis dan Cultural Studies. Yogyakarta: Jalasutra.

Udasmoro, W. (2018). Dari Doing ke Undoing Gender: Teori dan Praktik dalam Kajian Feminisme.

Yogyakarta: UGM PRESS.

Wells, L. (2015). Photography: A Critical Introduction Photography: Fifth Edition. Abingdon: Routledge. 
Wicaksono, I. P. (2012). Representasi Eksploitasi Perempuan dalam Iklan. Mediator: Jurnal Ilmu Komunikasi, 9(2), 149-168.

Widyatama, R. (2007). Pengantar Periklanan. Yogyakarta: Pustaka Book Publisher.

Indies, E. M. (28 November 2018). A Comprehensive Timeline of Dolce $\mathcal{E}$ Gabbana's Most Problematic Moments. Diakses dari https://fashionmagazine.com/style/stefano-gabbana-offensive-timeline/ 